\title{
MAJOR CHANGES INTHE WORLD SITUATION AFTER THE IRAQ WAR
}

\section{By Mohamed Jawhar Hassam (Malaysia)}

\section{Introduction}

The invasion and occupation of Iraq is destined, like the September 11 attacks, to be a watershed event of the early $21^{\text {st }}$ century. It marks the first time since the end of the colonial era that an Arab nation was invaded and occupied by an essentially Western power. But the political, economic and security ramifications go well beyond Iraq and the Middle East, to Europe and the United States itself, and indeed to the rest of the world.

It is useful to begin by pointing out the difficulty of isolating the Iraq variable from other major events that are impacting upon the world. The most important of these are the US-led campaign against terrorism, the handling of the Palestinian issue and Afghanistan. All these factors are having major consequences on the global situation, and they are inextricably intertwined with the Iraq variable.

It is also difficult to speak about the major changes in the global situation following the war on Iraq because these changes are still in the making. It is only 12 months since the attack on Iraq, and 12 months is a very short time to gauge strategic global shifts. We must be mindful too of the consequences of the consequences. It is not easy to be prescient in the midst of a rapidly altering landscape.

On one thing we can be reasonably sure though. There will be no victors. All, with the possible exception of Israel, are losers. When everything is said and done and we tot up all the political, financial, and humanitarian and security costs and benefits for all the different parties, the world was much better of before the attack on Iraq than now. One litmus test is if any of us feels any safer now than we did before the invasion, and how extreme the security measures have to be when some of our leaders travel and visit.

\section{Impact on international law and norms}

One immediate casualty of the invasion of Iraq was international law, international norms and accepted principles of state behavior. These laws, norms and principles have been violated before by many countries, but rarely are they violated by the very countries that moralize and preach these standards 
for others. When even those who conceive of themselves as the guardians of global order, with the greatest capacity to uphold it, can violate its legal and normative fundamentals that order is at grave risk.

International law and international norms have been undermined not only by the illegal attack on Iraq, but also by talk of regime change and a doctrine of preventive war and pre-emptive attack, and the reform of international law to accommodate it.

This strikes at the very heart of the international order. It counts as nought the laws and principles of respect for sovereignty and territorial integrity, nonaggression, and non-use of force in the settlement of disputes except in selfdefense. The prerogative for launching preventive war and pre-emptive attack can only be exercised by powerful states. They cannot be exercised by lesser powers.

Arguably, the doctrine of pre-emptive attack is not altogether indefensible. If one clearly knows that a grave and imminent threat to oneself is building up in another country and the only recourse is a pre-emptive attack, this should be permissible as a legitimate act of self-defense. But the decision cannot be made by one state and a few allies, and the evidence cannot be murky. To be moral and permissible, the bulk of the international community must support the action, and above all, the evidence must be clear and beyond reproach. To be legal, legitimacy has to be provided by the UN.

To be sure, observance of international law and international norms is not totally destroyed or absent. It continues to be exercised in many cases, not least by those who breached them in the case of Iraq, it will also continue to be upheld by them in the future. But it cannot be a matter of convenience, to be observed when desirable and ignored when not. Worse, it cannot be standard to be enforced only upon and observed by others and not by us.

\section{Impact on the United Nations, Unilateralism and Multilateralism}

Many assert that the attack on Iraq and its aftermath has led to a serious undermining of the credibility and efficacy of the United Nations. In some very critical ways this is certainly so. The invasion of Iraq was executed without UN approval and legitimacy. Occupation is proceeding without the world body being the final authority and without a major role for it. Political structures and practices are being introduced without the imprimatur of the UN. 
The UN has been used cynically by some states. It is supported and used when it serves their purpose. It is not only abandoned, but also roundly ridiculed and condemned when it does not approve their objective. It is called " irrelevant ".

Fortunately for the world, this is not entirely so for the large majority of nations. The $\mathrm{UN}$ is far from perfect. It is one of the most unequal and inequitable organizations ever created. It is in dire need of comprehensive reform.

But the UN remains of fundamental and indispensable importance to the overwhelming majority of nations. For them it is far from irrelevant. They continue to recognize the UN as the ultimate source of authority and legitimacy for matters affecting war and peace. The UN remains at the centre of many activities affecting global peace, security and prosperity. It continues to be the principal venue for debate and negotiation among the nations of the world.

In the case of Iraq, the UN failed in not being able to prevent the invasion and occupation of the country without just and sufficient cause. But it succeeded in denying the action the all-important legitimacy and moral standing it needed. The UN succeeds or fails not because of its own strengths and weaknesses but because of the machinations of its most powerful constituent members.

If one of the key features of the invasion and occupation of Iraq is the unilateral behavior of the world's only super hyperpower, the aftermath is also driving home the limits of unilateralism and hyperpowerdom. The immediate lesson is that weak but large states like Iraq can be easily defeated by an overwhelmingly superior military force. But extended occupation in the face of firm resistance as well as reconstruction cannot be effected without severely straining the resources of the occupying power. Multilateral support and participation are necessary for this purpose. Even more critical in the case of Iraq, there can be no legitimacy for coalition action and political change without $\mathrm{UN}$ approval.

The UN and multilateralism are therefore making a strong comeback, but it would be nanve to imagine that the US under this administration at least has eschewed unilateralism when it is perceived as in the national interest. The temptation to go it alone, or with a few states in tow in a coalition of the willing, will be especially strong so long as American policy is driven by those in positions of influence in Washington now.

\section{Increase in American "hard" power, decline in "soft" power}

In the wake of September 11, Afghanistan and Iraq, the United States has gained tremendously in terms of " hard " power. It has bases and troops in 
many more countries than it did before, in the Middle East, in Central Asia and in Southeast Asia. Russia has lost some of its traditional sphere of influences, and China is encircled even more than before. Massive increases in the allocation for defense (US\$ 378.6 billion for FY 2003, up more than a fifth from the FY 2001 allocation of US\$ 309.9) are widening even further the military gap between the US and the rest of the world.

While on the one hand initiating an intensified campaign against weapons of mass destruction in selected countries, the US itself is also diversifying and enhancing its nuclear arsenal with the development of small nuclear bombs for deployment in conventional war.

The increase in US hard power however has been at the expense of the " soft " power. US image and prestige has declined in many parts of the world. As numerous opinion polls such as those conducted by non-partisan Pew Research Center, Associated Press and Eurobarometer indicate, much goodwill has been lost, and the US under Bush is perceived by many as a menacing power.

The latest Pew Research Center poll, conducted in nine countries before the Madrid bombings and made public just days ago ( on 18 March ), is illuminative. It notes that the image of the US has declined sharply since 1991 and has never been lower as at present. Hardly one in six Germans and French has a favorable view of President Bush. Only 7 percent of Pakistanis have a favorable view. In Britain, where support is greatest, no more than 39 percent have a favorable view.

An earlier poll conducted by AP in eight countries ( the US, Canada, Britain, France, Italy, Germany, Mexico and Spain ) in February 2004 came to broadly similar conclusions. As the Toronto Star (4 March 2004 ) put it, “people living in all the countries except the United States have an unfavorable view of the role President George W. Bush plays in world affairs. Only in the United States did a majority, 57 percent, have a positive view..." Just over half in Mexico and Italy, and two-thirds in Britain and Canada, had a negative view. In Spain three-quarters had a negative view. In France and Germany more than four- fifths had a negative view.

If the present Bush administration has managed to alienate this many people in the Western world, one can easily imagine the sentiment in the Arab and Muslim world.

In pointing out the serious erosion in American soft power however, one must note that alienation and negative sentiment abroad is towards the policies of the Bush administration rather than America as a country, or even Americans 
in general. The Pew polls results are clear on this. The US as a country continues to attract much admiration for its impressive accomplishments in many fields, and not least for many aspects of its democracy at home.

This also indicates that if the US were to change its policies, its will still be able to recoup some of its lost soft power.

\section{Impact on Regional Cooperation and Solidarity}

The attack on Iraq led to serious rifts among old friends and traditional allies. The rift in the Atlantic alliance is only mending slowly, and the defeat of the Aznar government in the recent elections in Spain is again further strengthening sentiment in Europe against the US handling of Iraq. Rifts have also developed within Europe and the Middle East as states take sides, and regional solidarity has been undermined as a result. In Europe for instance, Britain, Aznar's Spain, Italy, Poland and the new Eastern European states lined up with the US, while France, Germany, Belgium and Luxembourg, along with Russia, lined up against.

It is unlikely however, that NATO, the EU or the Arab League and similar alliances and regional organizations will suffer permanent damage or become any weaker than they already are in the long run simply because of Iraq. The rifts will mend as the issue of Iraq recedes and other overarching strategic unifying factors re-assert themselves. How a political solution is worked out in Iraq will also exert a critical influence.

\section{Impact on International Terrorism and the Campaign Against International Terrorism}

Any discussion of changes in the world situation following the invasion and occupation of Iraq cannot ignore the consequences on international terrorism, forewarned by many but not heeded. Some notable successes have been scored against the Al-Qaeda and Al-Qaeda-linked terrorist movements like the Jemaah Islamiyah in Southeast Asia. The Al-Qaeda has lost its patron state and is scattered. But at the same time the coalition invasion and occupation of Iraq is contributing to strengthening the environment for international terrorism, that is terrorism directed at the interests of the US and its allies. The terrorists have found fresh resolve, new anger, a new cause, new recruits and new sympathizers. The invasion and occupation of Iraq has provided another major rallying point for the Al-Qaeda network. 
Hostility that was initially focused on the United States, United Kingdom and Australia besides Israel has spread to other countries that have contributed to the occupation and countries that have expressed their intention to contribute troops. Spain became a target on 11 March, 2004. Japan, which was never target of the Al-Qaeda, suddenly found itself also in the list. However in Iraq itself it is insurgency rather than terrorism that is driving the attacks on coalition forces although Osama bin Laden has urged the Iraqi people to fight the occupation.

All this means that the campaign against international terrorism has become more difficult and complicated. Targets world-wide will not only be the interests of the US, UK, Israel and Australia as before, but also the interests of countries like Italy and others as well that, like Spain, have dispatched troops to Iraq. These countries are in fact specifically cited in the audiotape that came to surface in October last year, in which Osama bin Laden " reserved the right " to retaliate against any country that took part in the war against Iraq.

One important outcome of this is that it increases the security burden of other countries that are not implicated as well, for terrorists could just as easily mount retaliatory attacks against the interests of the targeted countries in the territory of these countries as well, as has happened in Indonesia, Pakistan and elsewhere.

Iraq therefore has been largely a liability for the campaign against international terrorism, not only for its primary targets, namely the US and its allies, but also for the other countries where coalition interests are located.

\section{An Intensified Initiative against Nuclear Proliferation and Weapons of Mass Destruction}

The September 11 attack and the attack on Iraq also marked a renewed offensive against nuclear proliferation and weapons of mass destruction spearheaded by the US. The move was prompted by concerns of threats to the US and its allies by suspected states and terrorists who are able to gain access to these weapons. The targets were the usual suspects- Iran, Syria, Libya and North Korea.

Any effort to limit and eliminate nuclear weapons and weapons of mass destruction is to be welcomed and deserves support. The current offensive however, continues to be marked by double standards. The most vociferous condemnations of the weapons and the most frenzied search for them are being led by states that possess the largest arsenal of these weapons, and especially 
by the US. Epithets like " rogue states " are being reserved for the states that are seeking to empower themselves with these weapons, while the major culprits continue to avoid taking significant steps to reduce and eliminate nuclear weapons. It is as if there is a conspiracy among nuclear weapons to keep mum about their obligations while they vigorously seek to deny the same weapons to others.

States that have newly acquired weapons such as Pakistan and India have also been excused after initial sanctions, while Israel is conveniently overlooked altogether. So long as global security continues to be plagued by such grossly unjust standards enforced by powerful vested states, there will always be states that will seek to arm themselves with similar capabilities, leading in sum to an unstable and insecure world order.

\section{Cleavage between Government and People in Democracies}

The invasion of Iraq has led to the curious spectacle of several governments acting contrary to the wishes of their people in supporting the US-led attack and occupation of Iraq. Alliance obligations and realpolitik considerations such as aid and assistance have been behind the decision of these governments. In democracies however, this contradiction is only sustainable when foreign policy and Iraq do not feature heavily in issues before the people during elections. Where if does, as in Spain earlier this month, the government becomes a casualty.

\section{Galvanization of People Power}

As the UN and its member states failed in their responsibility to check the US and its allies from acting unilaterally, people across states and continents were galvanized as never before and found common cause to condemn the attack on Iraq. Demonstrations were largest and most numerous in Europe, and prominent individuals who lent their voice to dissent included the Pope and Nelson Mandela.

As to be expected however, spontaneous outpourings of popular anger dissipated quickly after the event. While condemnation continues to be widespread and persistent in many countries, especially in the face of continued failure to find alleged weapons of mass destruction, no major institutionalized international networks of people power have emerged. 


\section{A Western Democracy Offensive in the Middle East}

The perceived need to rid the Middle East of an environment considered conducive to terrorism as well as the successful attacks on Afghanistan and Iraq have prompted the US and its allies to embark upon a more comprehensive plan to "pacify" the Middle East through political reform. The Group of 8 industrial nations is now considering the "Greater Middle East Initiative" proposed by Washington.

This plan shows every promise of inducing even greater instability and turmoil in the region, ensuring heightened anti-American and possibly antiWestern sentiment as well in the region for many more years to come if implemented in its present form. The plan calls for measures to introduce democratic reform, political freedom, equality for women, access to education and greater openness. While these are all laudable goals, its imposition on Arab nations without consultation and Arab involvement in a region that has been the victim of British and French imperialism is sure to evoke intense hostility and some instability. Already Egypt's President Hosni Mubarak has visited some European capitals expressing his opposition.

Democratic reform is a complicated process that cannot succeed and remain sustainable without leadership coming from indigenous forces. Outside powers can only assist and play a supportive role, unless they are dealing with a failed or defeated state that is completely at their disposal. The US and its allies must therefore tread warily in the region, lest they leave behind a situation much worse than what it is today.

Democratic reform can also lead to consequences entirely contrary to what the US is hoping for. Fully democratic elections in Palestine could conceivably lead to a victory for Hamas, which is perceived by a majority of Palestinians as fighting for national liberation against illegal Israeli occupation, just as direct election in Iraq could easily result in a Shiite-dominated government that is anti-US.

Another major flaw in the US-led offensive to induce democratic change in the Middle East is that it is premised on the assumption that if countries are democratic there would be an end to anti-American sentiment and terrorism directed at the US and its interests. Democracy can help eradicate terrorism when political oppression at home is the major root cause for the emergence of a terrorist movement. Such movements would target the oppressive host government, not the US. Terrorism directed at the US and its allies and antiAmerican sentiment is driven essentially by other factors. Most prominent 
among these is widespread anger at the illegal occupation of Palestinian land by Israel, a US ally armed and supported by Washington. The fact that successive US administrations including the Bush administration have sought to bring about a settlement in the Middle East has not diminished anger at the US, because every plan hatched in Washington has been blatantly biased in favor of Israel. Differences are only a matter of degree.

\section{Conclusion}

The attack on Iraq has created much more havoc than good to the regional and global situation. Further damage, at least in so far as Iraq is concerned, can be minimized if the US effectively and credibly hands over authority for reconstruction and nation building to the $\mathrm{UN}$, and supports the UN in its efforts fully. So far however, Washington has found it difficult to do so. Even as it seeks a face-saving exit strategy, it refuses to relinquish ultimate control.

A radical change in policy is required. Perhaps this will only be forthcoming under a new administration, or with a complete change of the guard in the defense and security establishment under a second Bush administration. 